\title{
Eicosatetraenoic Acid
}

National Cancer Institute

\section{Source}

National Cancer Institute. Eicosatetraenoic Acid. NCI Thesaurus. Code C68357.

A polyunsaturated long-chain fatty acid with a 20-carbon backbone and exactly 4 double bonds. Eight different isomers can be called by this name. 